\title{
Eelgrass restoration by seed maintains genetic diversity: case study from a coastal bay system
}

\author{
Laura K. Reynolds ${ }^{1, *}$, Michelle Waycott ${ }^{2}$, Karen J. McGlathery ${ }^{1}$, Robert J. Orth ${ }^{3}$, \\ Joseph C. Zieman ${ }^{1}$
}

\begin{abstract}
${ }^{1}$ Department of Environmental Sciences, University of Virginia, Charlottesville, Virginia 22904, USA
${ }^{2}$ School of Marine and Tropical Biology, James Cook University Townsville, Queensland 4811, Australia ${ }^{3}$ Virginia Institute of Marine Science, The College of William and Mary, Gloucester Point, Virginia 23062, USA
\end{abstract}

\begin{abstract}
Genetic diversity is positively associated with plant fitness, stability, and the provision of ecosystem services. Preserving genetic diversity is therefore considered an important component of ecosystem restoration as well as a measure of its success. We examined the genetic diversity of restored Zostera marina meadows in a coastal bay system along the USA mid-Atlantic coast using microsatellite markers to compare donor and recipient meadows. We show that donor meadows in Chesapeake Bay have high genetic diversity and that this diversity is maintained in meadows restored with seeds in the Virginia coastal bays. No evidence of inbreeding depression was detected ( $F_{\mathrm{IS}}-0.2$ to 0 ) in either donor or recipient meadows, which is surprising because high levels of inbreeding were expected following the population contractions that occurred in Chesapeake Bay populations due to disease and heat stress. Additionally, there was no evidence for selection of genotypes at the restoration sites, suggesting that as long as donor sites are chosen carefully, issues that diminish fitness and survival such as heterosis or out-breeding depression can be avoided. A cluster analysis showed that, in addition to the Chesapeake Bay populations that acted as donors, the Virginia coastal bay populations shared a genetic signal with Chincoteague Bay populations, their closest neighbor to the north, suggesting that natural recruitment into the area may be occurring and augmenting restored populations. We hypothesize that the high genetic diversity in seagrasses restored using seeds rather than adult plants confers a greater level of ecosystem resilience to the restored meadows.
\end{abstract}

KEY WORDS: Seagrass $\cdot$ Zostera marina $\cdot$ Restoration $\cdot$ Genetic diversity $\cdot$ Microsatellite DNA

\section{INTRODUCTION}

A high level of genetic diversity in plant populations is associated with increased benefits for plant survival and ecosystem services (Booy et al. 2000). The loss of genetic diversity may cause reduced adaptability to environmental change through loss of fitness (Reed \& Frankham 2003). In both marine and terrestrial systems, experimental studies have demonstrated the benefits of genetic diversity to the capacity of populations to resist stressors such as disease, predation, and physical disturbance (Zhu et al.
2000, Hughes \& Stachowicz 2004, Reusch et al. 2005, Johnson et al. 2006, Hughes \& Stachowicz 2011). In marine systems, lower genetic diversity in the seagrass Zostera marina (eelgrass) has been shown to reduce survivorship following disturbance (Hughes \& Stachowicz 2004, 2011, Reusch et al. 2005). In terrestrial systems, genetically diverse assemblages of primrose plants Oenothera biennis were found to serve as a better habitat and support more species of arthropods than less diverse assemblages (Johnson et al. 2006). Also, genetically diverse rice Oryza sativa fields have been found to be less susceptible to 
disease (Zhu et al. 2000). Given the positive benefits associated with higher levels of genetic diversity, it should be considered an essential component of ecosystem restoration.

Strategies to enhance the likelihood of increased genetic diversity through restoration focus on 2 alternatives. The first is to maximize the use of genetic resources incorporated into captive breeding programs. The second is to use the diversity present in natural populations. Both strategies have been adopted widely, such as when salmon hatcheries that have captive animals sourced from a variety of locations have been used to mitigate population declines in the wild (Waples 1991, 1994). Captive breeding and reintroduction of young into wild populations also have been employed as tactics to increase the genetic diversity of the endangered Hawaiian thrush and big horn sheep (Kuehler et al. 2000, Ostermann et al. 2001). However, this strategy, where material is sourced from a variety of origins, has also been criticized, because new genotypes are introduced into remnant populations and this potentially results in less fit progeny (Knapp \& Dyer 1998).

Many estuarine and coastal areas are experiencing increasing levels of disturbance and/or stress related to human activities, such as eutrophication, low dissolved oxygen, increasing temperatures, and invasive species (Jackson et al. 2001, Lotze et al. 2006, Halpern et al. 2008, Waycott et al. 2009). Knowledge of the value of the plant and animal species that occupy these habitats has resulted in significant efforts to reduce anthropogenic stressors and to emphasize restoration of species and habitats.

Seagrasses (marine angiosperms), of which there are approximately 72 species, are often the dominant macrophytes in estuaries, shallow coastal bays, and lagoons worldwide (Green \& Short 2003, Short et al. 2011). Globally, seagrasses are declining (Orth et al. 2006a, Waycott et al. 2009), most often as a result of increasing nutrients and sediments from watersheds being altered by human activities (Waycott et al. 2009). In many degraded systems efforts are being made to mitigate seagrass decline and to improve habitat for seagrass restoration (Greening \& Janicki 2006, Orth et al. 2010). There is a growing body of evidence that indicates that genetically diverse assemblages of seagrasses are fitter (Williams 2001) and more resistant to a variety of disturbances (Hughes \& Stachowicz 2004, 2011, Reusch et al. 2005). In the seagrass ecosystems dominated by a single species that are typical of northern hemisphere seagrass communities, adopting appropriate restoration strategies to capture adequate levels of genetic diversity is an important and realistic goal. Monospecific seagrass meadows can act as case studies for evaluating the relative success of implementing different restoration strategies based on maintaining genetic diversity.

Zostera marina is a seagrass found in temperate and sub-temperate regions of the North Atlantic and North Pacific Oceans and in the Mediterranean Sea (Green \& Short 2003). This species of seagrass has been observed to undergo periods of extreme population fluctuations, especially in the North Atlantic (Cottam 1934, 1935). The most notable broad-scale population decline was associated with the spread of Labyrinthula zosterae, a fungal parasite, in the 1930s (Rasmussen 1977). While many populations eventually recovered from the impact of this disease (Cottam \& Munro 1954), populations in a number of coastal bays in the mid-Atlantic region of the United States did not (Orth et al. 2006b). Most recovery in the Virginia coastal bays is the result of large-scale restoration (Orth et al. 2006b, 2012, this Theme Section). While the scale and success of the restoration in the Virginia coastal bays is somewhat unique, mitigation to compensate for seagrass loss through restoration is becoming more globally widespread (Paling et al. 2009, van Katwijk et al. 2009)

One concern surrounding seagrass restoration is the possible loss of genetic diversity when adult plants are used for re-establishing populations (Williams \& Davis 1996, Williams 2001). Depending upon the size of the clone, it is entirely possible that adult plants for a small-scale restoration effort could be drawn from a single clone with low genetic diversity. The use of seeds harvested from multiple parents, rather than adult plants, could offset this genetic bottleneck. The successful re-establishment of Zostera marina into unvegetated coastal bays in the mid-Atlantic region of the United States using seeds from a number of source beds (Orth et al. 2012) offered a unique opportunity to test the hypothesis that genetic diversity is not eroded when seeds are used as in restoration. Here we present results from our analysis of genetic diversity from both natural $Z$. marina beds in Chesapeake Bay, several of which have served as source beds for restoration, and the restored beds in the Virginia coastal bays.

\section{MATERIALS AND METHODS}

A total of 9 Zostera marina meadows were sampled in 3 distinct regions. These included both natural beds in Chesapeake Bay (mouth of the York River, 
$\mathrm{YR}_{i}$ Mobjack Bay, MB; Hungar's Creek, HC; and Fisherman Island, FI), 1 bay to the immediate north of the restoration sites (Chincoteague Bay, CB), and restored beds in 3 Virginia coastal bays (South Bay, $\mathrm{SB}$; Spider Crab Bay, $\mathrm{SC}_{\text {; }}$ and 2 sites in Hog Island Bay, HR6, HR7) (Fig. 1). These Virginia coastal bays are part of the Virginia Coast Reserve Long Term Ecological research site. Several of the Chesapeake Bay sites were sources of seeds (YR, MB, and $\mathrm{HC}$ ) used in the coastal bay restoration (Table 1). Restored beds sampled in South Bay were seeded from a variety of western Chesapeake Bay sources, including MB and YR. Restored beds sampled in Spider Crab Bay were seeded from SB seeds in 2008. Restored beds sampled in Hog Island Bay were seeded either from Hungar's Creek in 2006 (labeled HR6) or from South Bay (SB) in 2007 (labeled HR7).

Methods for collection, storage, and disbursing of seeds can be found in Marion \& Orth (2010). Because we were interested in whether genetic diversity would be maintained in restored beds developed with seeds, we compared donor sites and restored beds for genetic diversity, resulting in 7 comparisons of donor meadows and recipients. Natural populations at Fisherman Island (FI) and Chincoteague Bay (CB) were also sampled as they represent populations immediately south and north of the restored sites.

At each sampling site, whole eelgrass shoots were haphazardly collected by hand from areas approximately $5 \mathrm{~m}$ apart, to avoid collecting shoots from the same clones. Leaf tissue was dried and stored at room

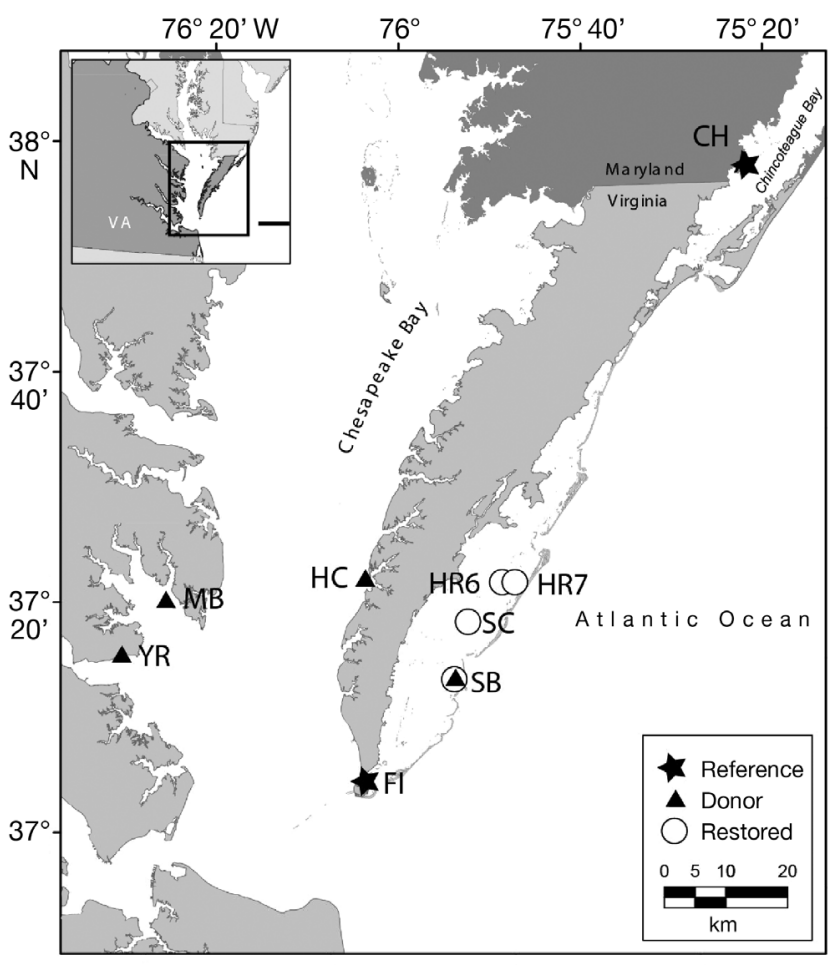

Fig. 1. Site map. Chincoteague Bay $(\mathrm{CH})$, Fisherman Island (FI), Hungar's Creek (HC), Mobjack Bay (MB), and York River (YR) are natural Zostera marina meadows. Seeds from various Chesapeake Bay sites including MB and YR were used to restore South Bay (SB). HC was used as a donor for HR6 in 2006, and seeds from the restored meadow in SB were used in a restoration in Hog Island Bay in 2007 (HR7) and in a restoration in Spider Crab Bay (SC) in 2008

Table 1. Zostera marina. Summary of multilocus genetic diversity estimates for all 9 populations based on 8 microsatellite loci. Sites refer to locations shown on Fig. $1 . N$ : sample size; $N_{\mathrm{A}}$ : total number of alleles per population; $A_{\mathrm{R}}$ : allelic richness; $A$ : average number of alleles per locus; $A_{<25 \%}$ : uncommon alleles; $H_{0}$ : observed heterozygosity; $H_{\mathrm{e}}$ : expected heterozygosity; F: Wright's inbreeding coefficient; VA: Virginia, USA

\begin{tabular}{|c|c|c|c|c|c|c|c|c|c|}
\hline Site & Site description & $N$ & $N_{\mathrm{A}}$ & $A_{\mathrm{R}}$ & $A$ & $A_{<25 \%}$ & $H_{\mathrm{o}}$ & $H_{\mathrm{e}}$ & $F$ \\
\hline Fisherman Island (FI) & $\begin{array}{l}\text { Southern natural meadow } \\
\text { at the mouth of Chesapeake Bay }\end{array}$ & 46 & 47 & 4.4 & 6.7 & 0.6 & 0.7 & 0.6 & -0.2 \\
\hline Hungar's Creek (HC) & Natural Chesapeake Bay meadow & 48 & 71 & 5.5 & 10.1 & 0.6 & 0.8 & 0.7 & -0.1 \\
\hline Mobjack Bay (MB) & Natural Chesapeake Bay meadow & 30 & 63 & 5.4 & 9.0 & 0.6 & 0.6 & 0.6 & 0.0 \\
\hline York River (YR) & Natural Chesapeake Bay meadow & 30 & 66 & 5.7 & 9.4 & 0.7 & 0.7 & 0.7 & 0.0 \\
\hline South Bay (SB) & $\begin{array}{l}\text { VA coastal bay meadow restored } \\
\text { in } 2002 \text { using seed from MB and YR }\end{array}$ & 95 & 79 & 5.6 & 11.3 & 0.7 & 0.7 & 0.7 & 0.0 \\
\hline Hog Island Bay (HR6) & $\begin{array}{l}\text { VA coastal bay meadow restored } \\
\text { in } 2006 \text { using seed from HC }\end{array}$ & 167 & 94 & 5.6 & 13.4 & 0.7 & 0.7 & 0.7 & -0.1 \\
\hline Hog Island Bay (HR7) & $\begin{array}{l}\text { VA coastal bay meadow restored } \\
\text { in } 2007 \text { using seed from SB }\end{array}$ & 46 & 66 & 5.3 & 9.4 & 0.7 & 0.8 & 0.7 & 0.0 \\
\hline Spider Crab Bay (SC) & $\begin{array}{l}\text { VA coastal bay meadow restored } \\
\text { in } 2008 \text { using seed from SB }\end{array}$ & 48 & 70 & 5.3 & 10.0 & 0.7 & 0.8 & 0.7 & -0.2 \\
\hline Chincoteague Bay $(\mathrm{CH})$ & $\begin{array}{l}\text { Northern natural VA } \\
\text { coastal bay meadow }\end{array}$ & 48 & 60 & 4.6 & 8.6 & 0.6 & 0.7 & 0.6 & -0.1 \\
\hline
\end{tabular}


temperature using silica gel desiccant (AGM, mixture of white and indicating beads) until DNA extraction. All plant samples were collected during the summer months (June to August) of 2008 and 2009.

Total genomic DNA was extracted using DNeasy plant extraction kits (Qiagen) following manufacturer's instructions. A total of 8 microsatellite loci previously used for this species (Reusch et al. 1999) were amplified using fluorescently tagged primers (CT17H, CT3, CT35, GA2, CT19, CT20, GA3, and GA6). Amplification of PCR products followed the procedures recommended by Reusch et al. (1999). PCR products were analyzed by capillary electrophoresis on a MegaBACE 1000 (GE Biosciences) with ET 400-Rox (GE Biosciences) internal size standard in each sample, as per manufacturer's instructions. Fragment lengths for each allele, at each locus, were determined using Fragment Profiler V1.2 (GE Biosciences).

Standard measures of genetic diversity were calculated for each population sampled. Allelic richness $\left(A_{R}\right)$, standardized to the smallest population size by rarefaction, was computed using FSTAT 2.9.3.2 (Goudet 2001). Total number of alleles per population $\left(N_{\mathrm{A}}\right)$, the average number of alleles per locus $(A)$, the average number of low-frequency alleles $\left(A_{<25 \%}\right)$ at each locus, the mean observed $\left(H_{0}\right)$ and mean expected heterozygosity $\left(H_{\mathrm{e}}\right)$, and Wright's inbreeding coefficient $(F)$ were calculated using GenAlEx 6.3 (Peakall \& Smouse 2006). Differences in genetic diversity between donor and recipient populations were analyzed using both a paired $t$-test and a chisquared goodness-of-fit test, where paired donor meadows were treated as expected values.

The population structure or relatedness of geographically separated meadows was compared using the standard measure of population differentiation, $F_{\text {st, }}$ calculated in GenAlEx 6.3 (Peakall \& Smouse 2006). Within-population inbreeding was estimating using $F_{\text {is, }}$ calculated in GenAlEx 6.3 (Peakall \& Smouse 2006). A test of population assignment using Bayesian modeling of all samples was conducted using the software STRUCTURE for assigned numbers of populations of $K=1$ to 10 and with 10 replicates with a random start for each value of $K$ (Pritchard et al. 2000). The number of distinct population clusters was determined using the delta $K$ method (Evanno et al. 2005). The relationship between the cluster to which a sample was assigned and geographic origin were analyzed with a KruskalWallis 1-way analysis of variance. Pairwise differences were analyzed with individual Mann-Whitney $U$-tests, with Bonferroni-corrected alpha values.

\section{RESULTS}

Moderate to high levels of allelic diversity were detected across the 9 Zostera marina meadows sampled from the Chesapeake Bay, Virginia coastal bays, and Chincoteague Bay. All loci conformed to HardyWeinberg equilibrium in at least some of the populations. All populations sampled showed relatively high allelic richness (mean $A_{R}=5.3$ ), with York River having the highest value at 5.7 and Fisherman Island having the lowest value at 4.4. Across all sites both the observed (mean $H_{0}=0.72$ ) and expected (mean $H_{\mathrm{e}}=0.67$ ) heterozygosities were high, which is typical of Z. marina. Although in many population samples $H_{\mathrm{o}}$ was greater than $H_{\mathrm{e}}$ which resulted in slightly negative inbreeding coefficients $(F=-0.2$ to 0$)$, the $F$-values were not significantly different (Table 1).

Restored meadows did not show a significant reduction in allelic richness, mean number of rare alleles, or expected heterozygosity relative to their donor meadows (Fig. 2). A paired t-test between donor and recipient meadows resulted in p-values of 0.39 or greater, and a chi-squared goodness-of-fit using donor values as expected values resulted in $\mathrm{p}$ values equal to or greater than 0.98 . The inbreeding coefficient within populations $\left(F_{\text {is }}\right)$ approached zero, and there was no significant deviation between donor and recipient pairs (Fig. $2 ; t=0.62$, p $=0.58$ and $\chi^{2}=1.08, \mathrm{p}=0.77$ ).

All Chesapeake Bay sites and restored Virginia coastal bay sites were closely related when analyzed with permuted $F_{\text {st }}$ values $(<0.1)$. Higher pairwise $F_{\text {st }}$ values were observed in comparisons with Fisherman Island and Chincoteague Bay. This was expected as these sites acted as external non-donor recipient reference sites for the present study. Fisherman Island had pairwise $F_{\text {st }}$ values $>0.1$ with all other meadows. Chincoteague Bay showed a similar deviation from Chesapeake Bay and South Bay sites; however, it had lower pairwise $F_{\text {st }}$ values when compared with Hog Island (2006 and 2007) and Spider Crab Bay, the more northerly restored Virginia coastal bay sites (Table 2).

The relative distinctiveness of sampled meadows was assessed by assigning individuals based on genetically homogenous groups, rather than on sampled locations, using a Bayesian cluster approach with the software STRUCTURE (Pritchard et al. 2000) and by implementing the ad hoc statistic $(\Delta K)$ (Evanno et al. 2005). The highest values for the $\Delta K$ statistic identify 4 groups, or genetic populations, that were present among the 9 sampled locations 

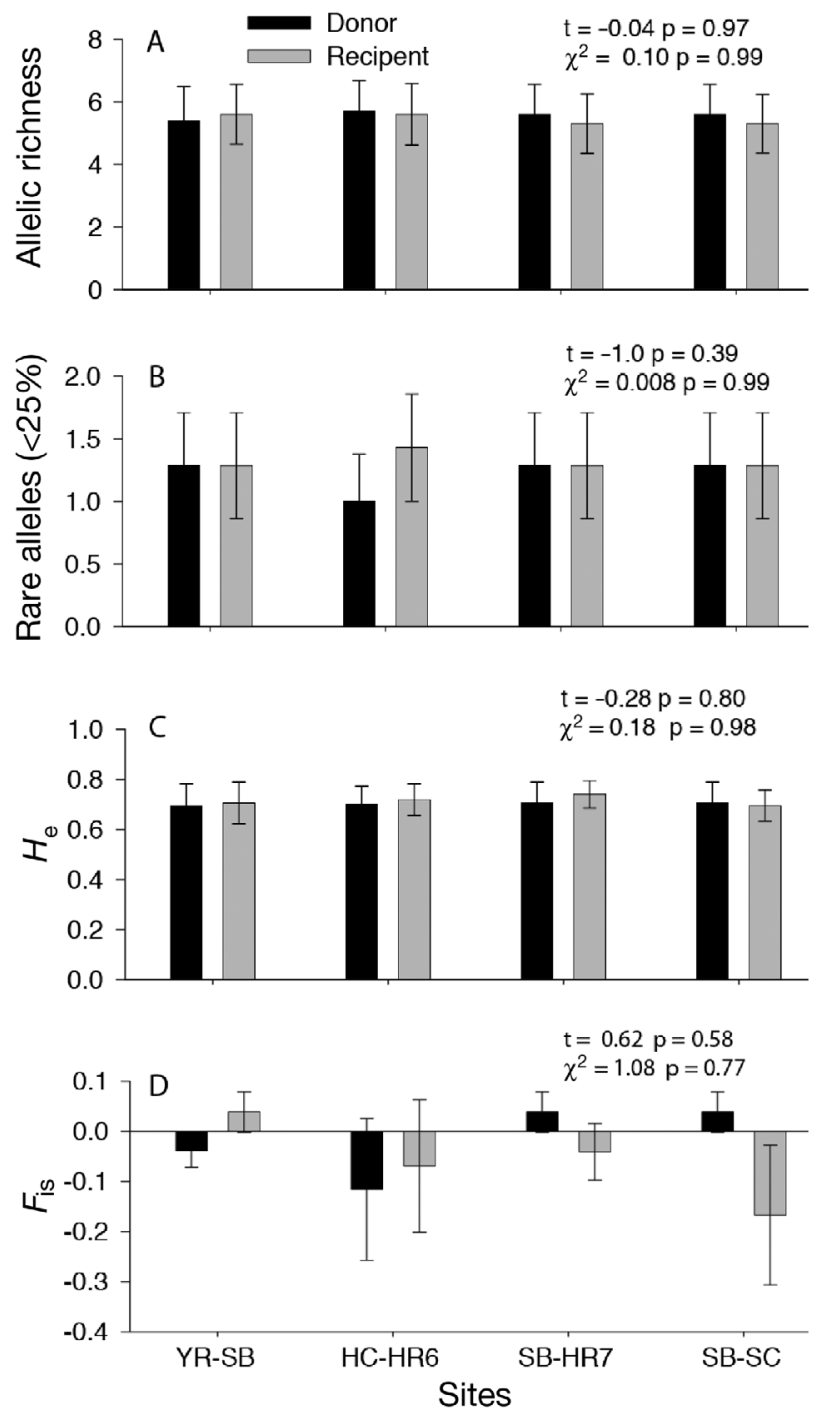

Fig. 2. Zostera marina. Four measures of genetic diversity were used to compare donor (dark) and recipient (light) eelgrass meadows $( \pm \mathrm{SE})$ : (A) allelic richness, (B) frequency of rare alleles $(<25 \%)$ per population, $(C)$ expected heterozygosity $\left(H_{\mathrm{e}}\right)$, and (D) Wright's inbreeding coefficient $(F)$. Site abbreviations, see Fig. 1
(Fig. 3). Samples from different geographic locations were assigned to each of these 4 different clusters with high probability (Kruskal-Wallis: $\chi^{2}=72$, $\mathrm{p}<0.0001)$. Significant differences in pairwise comparisons, made with individual Mann-Whitney $U$ tests using a Bonferroni corrected alpha of 0.001, were observed for many of the comparisons, particularly between reference sites and the donor-recipient locations (Table 3). The southern-most site near the mouth of the Chesapeake Bay, Fisherman Island (FI), was assigned to Cluster 4 and was significantly distinct from each of the other locations. All Chesapeake Bay locations ( $\mathrm{HC}, \mathrm{YR}, \mathrm{MB}$ ) and the restored meadow at South Bay (SB) were assigned to both Clusters 1 and 2; however, they were not significantly different from one another. The Hog Island Bay beds restored in 2006 (HR6) were not different from the donor meadow of Hungar's Creek (HC). HR6 differed from the York River site and the South Bay site. The Hog Island Bay beds restored in 2007 (HR7) were not different from the South Bay donor meadow, but like HR6 differed from the York site. The Spider Crab Bay site (SC) was similar to the South Bay donor site, as well as the restorations in Hog Island Bay. The northern natural Virginia coastal bay site, Chincoteague Bay, differed from Fisherman Island, all Chesapeake Bay sites, and the older restoration sites of South Bay and HR6. Spider Crab Bay and HR7 were not statistically different from Chincoteague Bay (Table 3).

The proportional assignment of individual samples to each of the 4 modeled genetic clusters supports the observation that the diversity in the restored meadows was equivalent to that in the donor meadows (Fig. 4). Fisherman Island was distinctive, with few individuals from other sites having a high likelihood of sharing this group; these were assigned to Cluster 4 (Fig. 4). Chesapeake Bay samples (HC, MB, YR), as well as the restored meadows in the Virginia coastal

Table 2. Zostera marina. Pairwise $F_{\text {st }}$ estimates for all 9 Z. marina populations based on 8 microsatellite loci. *Values not significantly different from zero

\begin{tabular}{|c|c|c|c|c|c|c|c|c|c|}
\hline & FI & $\mathrm{HC}$ & $\mathrm{MB}$ & YR & SB & HR6 & HR7 & $\mathrm{tSC}$ & $\mathrm{CH}$ \\
\hline Fisherman Island (FI) & 0.000 & & & & & & & & \\
\hline Hungar's Creek (HC) & 0.124 & 0.000 & & & & & & & \\
\hline Mobjack Bay (MB) & 0.187 & 0.048 & 0.000 & & & & & & \\
\hline York River (YR) & 0.159 & 0.031 & 0.012 & 0.000 & & & & & \\
\hline South Bay (SB) & 0.143 & 0.019 & 0.014 & $0.005^{*}$ & 0.000 & & & & \\
\hline Hog Island Bay (HR6) & 0.117 & 0.006 & 0.056 & 0.031 & 0.023 & 0.000 & & & \\
\hline Hog Island Bay (HR7) & 0.114 & 0.030 & 0.095 & 0.062 & 0.044 & 0.018 & 0.000 & & \\
\hline Spider Crab Bay (SC) & 0.109 & 0.026 & 0.082 & 0.051 & 0.046 & 0.014 & 0.037 & 0.000 & \\
\hline Chincoteague Bay $(\mathrm{CH})$ & 0.136 & 0.092 & 0.148 & 0.111 & 0.095 & 0.064 & 0.067 & 0.023 & 0.000 \\
\hline
\end{tabular}


bays, were similar and assigned across Clusters 1 and 2. Neither Cluster 1 nor 2 was specific to 1 location (Fig. 4). Chincoteague Bay samples were distinct and assigned to Cluster 3, along with numerous samples in the Virginia coastal bays, especially Hog Island Bay, which is closest in proximity (Fig. 4). The same patterns persisted when data were grouped as averages of plants collected from 1 location (Fig. 4).

\section{DISCUSSION}

Our results demonstrate that the restoration of Zostera marina with seeds in Virginia coastal bays has maintained overall population genetic structure and diversity compared to the donor populations. This finding is in contrast to the significant reduction in genetic diversity observed in a restored $Z$. marina meadow in Southern California, USA, where adult plants were used in the restoration effort and were collected from a very small area (200 to $12000 \mathrm{~m}^{2}$ ) (Williams \& Davis 1996, Williams 2001). A genetically diverse donor population is required to achieve a genetically diverse restored population, and this was the case with Chesapeake Bay and the Virginia

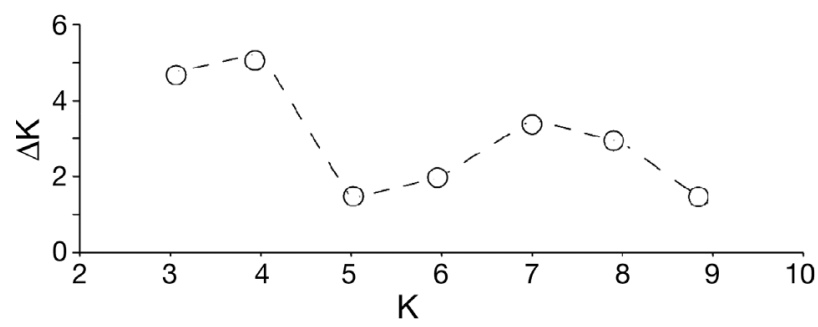

Fig. 3. The 9 geographically separated Zostera marina meadows sampled were grouped into 4 genetically distinct clusters based on the ad hoc statistic $\Delta K . \Delta K$ was calculated based on 10 runs of the model following Evanno et al. (2005) coastal bays. Despite population fluctuations in Chesapeake Bay's Z. marina populations in the last $80 \mathrm{yr}$, since the 1930s decline (Orth \& Moore 1983, 1984, Orth et al. 2010), current populations exhibit relatively high genetic diversity (Tables 1 \& 4).

In the restoration efforts evaluated here, measures of genetic diversity and levels of inbreeding did not differ between the paired donor meadows and recipient meadows (Fig. 1). There is no evidence currently that genotypes are being selected for in the restoration sites. Donor and recipient pairs appear as highly connected, undifferentiated population pairs through high gene flow and low $F_{\text {st }}$ values $\left(N_{\mathrm{m}}\right.$ ranges between 4.95 and 8.61, while $F_{\text {st }}$ ranges between 0.005 and 0.05), and this supports the conclusion that the donor and recipient populations are genetically comparable. We propose that the success in maintaining genetic diversity in restored populations of the Virginia coastal bays is due to a combination of high levels of genetic diversity present in the donor meadows, collection of seeds from a broad area that does not result in oversampling of closely related individuals, and the introduction of adequate numbers of seeds into donor sites in a manner reflecting relatively 'natural' recruitment processes. While this is an improvement over previous analyses of restorations using adult plants (Williams \& Davis 1996, Williams 2001), those studies incorporated plants that were collected from a small area and restorations were relatively small in numbers of transplant units. If adult plants were collected from a large area within a genetically diverse region, reductions in genetic diversity could be improved; however, logistically, it is easier to collect and transplant large numbers of seeds than to transplant large numbers of adult plants. This is underscored by the small scale ( $<0.5$ ha) of most adult transplant restoration efforts (Paling et al. 2009).

Table 3. The Zostera marina samples from each of 9 geographically separated meadows were assigned to different genetically distinct clusters using STRUCTURE. Mann-Whitney $U$-tests were used to determine differences in populations, and p-values are reported

\begin{tabular}{|lclllllll}
\hline & FI & HC & PC & PR & SB & HR6 & HR7 & SC \\
\hline Fisherman Island (FI) & & & & & & & \\
Hungar's Creek (HC) & $<0.0001$ & & & & & & \\
Mobjack Bay (MB) & $<0.0001$ & 0.4 & & & & & \\
York River (YR) & $<0.0001$ & 0.004 & 0.2 & & & & \\
South Bay (SB) & $<0.0001$ & 0.2 & 0.9 & 0.202 & & & \\
Hog Island Bay (HR6) & $<0.0001$ & 0.06 & 0.004 & $<0.0001$ & $<0.0001$ & & \\
Hog Island Bay (HR7) & $<0.0001$ & 0.03 & 0.002 & $<0.0001$ & 0.0003 & 0.05 & \\
Spider Crab Bay (SC) & $<0.0001$ & $<0.0001$ & $<0.0001$ & $<0.0001$ & 0.002 & 0.0004 & 0.9 \\
Chincoteague Bay (CH) & $<0.0001$ & $<0.0001$ & $<0.0001$ & $<0.0001$ & $<0.0001$ & $<0.0001$ & 0.12 & 0.004 \\
\hline
\end{tabular}




$\begin{array}{cccc}\text { Natural } & \text { Chesapeake } & \text { Restored } & \text { Northern } \\ \text { Meadow at } & \text { Bay } & \text { Virginia } & \text { Natural } \\ \text { the Mouth of } & \text { Donor } & \text { Coastal Bay } & \text { Virginia } \\ \text { Chesapeake } & \text { Meadows } & \text { Meadows } & \text { Coastal Bay } \\ \text { Bay } & & & \text { Meadow }\end{array}$
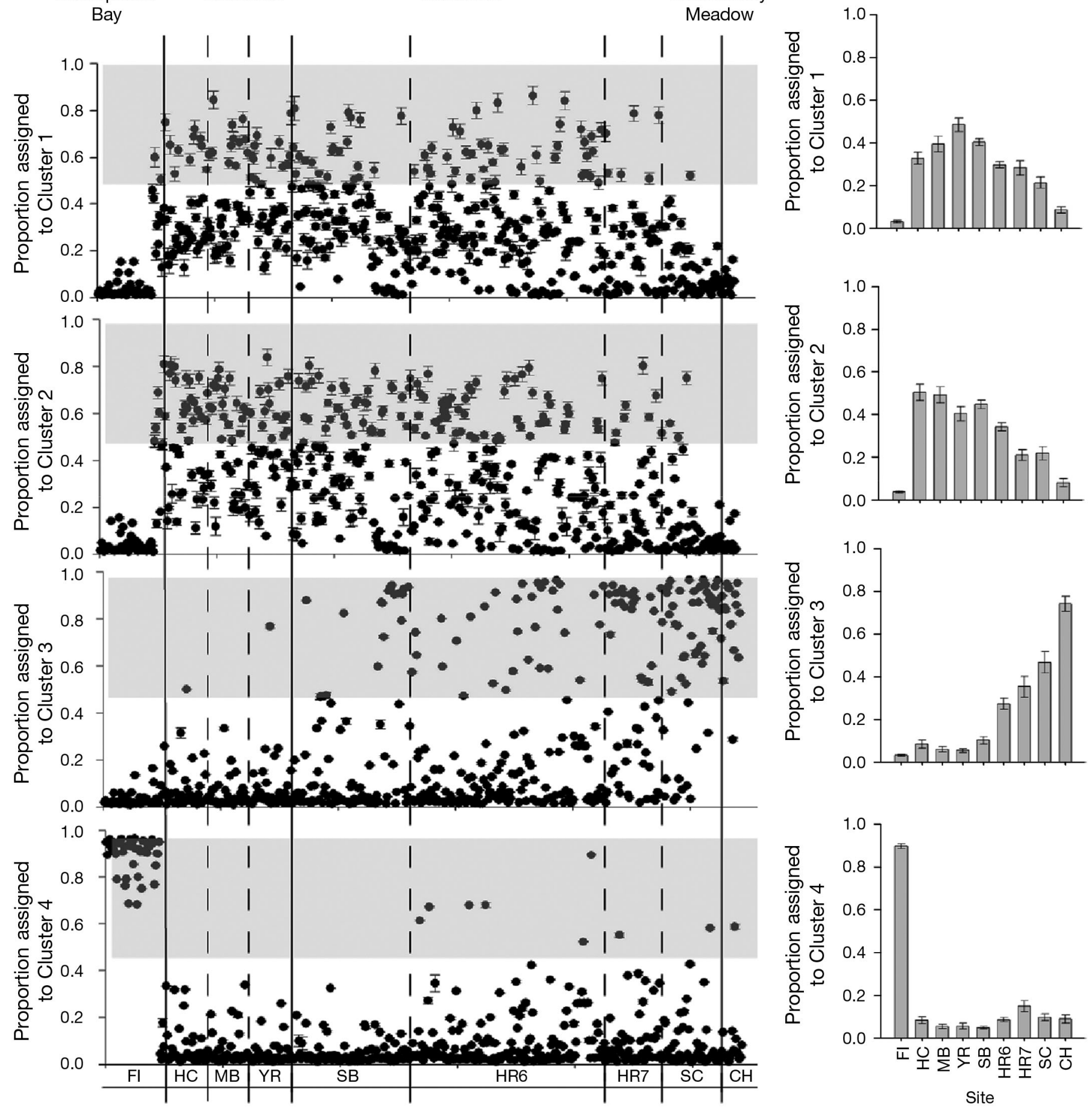

Fig. 4. Zostera marina. Each sample was assigned to 1 of 4 genetic clusters using the Bayesian cluster model STRUCTURE (Pritchard et al. 2000), and samples tended to cluster regionally. Plots of outcomes for proportional assignments of individual samples to each of the 4 genetic clusters based on 10 independent runs are presented. For each panel, the left plot depicts the mean proportional assignment $( \pm \mathrm{SE})$ for each individually sampled seagrass shoot; the grey shaded area highlights where assignment to the cluster was $>0.5$. The right plot depicts the mean proportion assigned to that genetic cluster for all samples collected within that location ( \pm SE). Samples are arranged by geographical location from south to north. Site abbreviations, see Fig. 1 
Table 4. Zostera marina. Summary of multilocus microsatellite-based genetic diversity around the world. $A_{\mathrm{R}}$ : allelic richness; $A$ : average number of alleles per locus; $H_{\mathrm{e}}$ : expected heterozygosity; $F_{\text {is }}$ : inbreeding coefficient

\begin{tabular}{|c|c|c|c|c|c|}
\hline Location & $A_{\mathrm{R}}$ & $A$ & $H_{\mathrm{e}}$ & $F_{\text {is }}$ & Source \\
\hline \multicolumn{6}{|l|}{ Eastern Pacific } \\
\hline $\begin{array}{l}\text { San Juan Archipelago, } \\
\text { Washington, USA }\end{array}$ & $2.3-3.1$ & $2.5-10.4$ & $0.29-0.51$ & -0.11 to 0.05 & Wyllie-Echeverria et al. (2010) \\
\hline $\begin{array}{l}\text { San Francisco Bay, } \\
\text { California, USA }\end{array}$ & $2.7-5.4$ & $3.1-6$ & $0.24-0.60$ & -0.2 to 0.19 & $\begin{array}{l}\text { Talbot et al. (2004) } \\
\text { Ort et al. (2010) }\end{array}$ \\
\hline $\begin{array}{l}\text { Eastern Pacific, } \\
\text { USA and Canada }\end{array}$ & $4.9-6.4$ & & $0.17-0.51$ & -0.14 to 0.16 & Olsen et al. (2004) \\
\hline Baja California, Mexico & & $1.5-4.0$ & $0.13-0.54$ & -0.04 to 0.36 & Coyer et al. (2007) \\
\hline \multicolumn{6}{|l|}{ Western Pacific } \\
\hline Mikawa Bay, Japan & & $10.5-12$ & $0.70-0.85$ & -0.04 to 0.03 & Yoshida et al. (2009) \\
\hline \multicolumn{6}{|l|}{ Eastern Atlantic } \\
\hline Baltic Sea, Germany & & $5-5.9$ & $0.40-0.44$ & -0.02 to 0.09 & Reusch et al. (2000) \\
\hline Baltic Sea, Finland & 1.17 & & $0.17-0.44$ & -0.67 to 0.01 & Olsen et al. (2004) \\
\hline Margot, France & 3.33 & & 0.32 & 0.01 & Reusch et al. (2000) \\
\hline Eastern Atlantic, Europe & $1.5-2.7$ & & $0.33-0.52$ & -0.26 to 0.038 & Olsen et al. (2004) \\
\hline \multicolumn{6}{|l|}{ Western Atlantic } \\
\hline Nova Scotia, Canada & 5.67 & & 0.46 & -0.022 & Reusch et al. (2000) \\
\hline $\begin{array}{l}\text { Western Atlantic Ocean, } \\
\text { USA and Canada }\end{array}$ & $2.9-4.9$ & & $0.41-0.56$ & -0.09 to 0.19 & Olsen et al. (2004) \\
\hline $\begin{array}{l}\text { New Jersey coastal } \\
\text { bays, New Jersey USA }\end{array}$ & & $6.8-10.5$ & $0.69-0.83$ & 0.55 to 0.71 & Campanella et al. (2009) \\
\hline $\begin{array}{l}\text { Chesapeake Bay, } \\
\text { Virginia, USA }\end{array}$ & $5.4-5.7$ & $9-10.1$ & $0.6-0.7$ & -0.1 to 0 & Present study \\
\hline $\begin{array}{l}\text { Virginia Coastal Bays, } \\
\text { Virginia, USA }\end{array}$ & $4.6-5.6$ & $6.7-9.1$ & $0.6-0.7$ & -0.2 to 0 & Present study \\
\hline
\end{tabular}

Using seeds from local or regional provenances that are likely locally adapted to appropriate environmental conditions would enhance restoration success. In addition to immediate restoration outcomes, the presence of high levels of genetic diversity in restored populations suggests that the populations will be less likely to show signs of genetic erosion.

Overall, our estimates of genetic diversity are high, but are consistent with the range of values observed in previous studies (Table 4). Olsen et al. (2004) found an insignificant trend of increased diversity with decreased latitude along the western Atlantic coast. Our study adds additional data from closer to the geographic margin of the species, and further supports the observation of a trend of increased diversity with decreased latitude. Compared to the western Atlantic and eastern Pacific populations studied (Reusch et al. 2000, Olsen et al. 2004, Talbot et al. 2004, Coyer et al. 2007, Ort et al. 2010, WyllieEcheverria et al. 2010), the Chesapeake and Virginia coastal bay populations described here are more diverse. The only meadows found to have higher values of heterozygosity and numbers of alleles per locus were in Mikawa Bay, Japan (Yoshida et al. 2009; Table 4, present study). The high levels of diversity found in Virginia were unexpected due to the population history of Zostera marina in the region. Over the last century, the $Z$. marina meadows in Virginia have experienced many disturbances including disease, reduced water quality and clarity, bioturbation by rays, and high temperature stress (Orth 1975, 1976, Orth \& Moore 1984, Moore \& Jarvis 2008). The large-scale decline of $Z$. marina populations in the 1930s, which was attributed to disease (Orth \& Moore 1984), would be expected to have created a population bottleneck, with subsequent high levels of inbreeding and reduced genetic diversity in remnant populations in the Chesapeake Bay and Chincoteague Bay. While a recently published study found that $Z$. marina populations from both New Jersey and 1 site in the Chesapeake Bay showed significant signs of inbreeding ( $F_{\text {is }}>0.6$; Campanella et al. 2009) (Table 4), our data from Chesapeake and Chincoteague $Z$. marina meadows do not, despite finding similar levels of allelic diversity.

The mechanism by which natural seagrass meadows in Virginia maintain such a high diversity may be quite similar to the mechanism by which restoration by seed maintains high genetic diversity: large numbers of seeds added to open space. The disturbances in Chesapeake Bay (i.e. Orth 1975, 1976, Orth \& Moore 1984, Moore \& Jarvis 2008) remove seagrass, 
Table 5. Zostera marina. Pairwise estimates of gene flow for all 9 populations based on 8 microsatellite loci. Values above the diagonal are $N_{\mathrm{m}}$ values calculated based on $F_{\mathrm{st}}$ in GenAlEx 6.3 (Peakall \& Smouse 2006), and values below the diagonal are calculated based on rare alleles using GenePop (Raymond \& Rousset, http://wbiomed.curtin.edu.au/genepop/index.html)

\begin{tabular}{|c|c|c|c|c|c|c|c|c|c|}
\hline & FI & $\mathrm{HC}$ & $\mathrm{MB}$ & YR & SB & HR6 & HR7 & $\mathrm{SC}$ & $\mathrm{CH}$ \\
\hline Fisherman Island (FI) & & 1.762 & 1.084 & 1.325 & 1.494 & 1.883 & 1.948 & 2.037 & 1.588 \\
\hline Hungar's Creek (HC) & 1.168 & & 5.006 & 7.763 & 13.249 & 42.906 & 7.988 & 9.348 & 2.469 \\
\hline Mobjack Bay (MB) & 0.516 & 5.608 & & 20.989 & 18.067 & 4.193 & 2.387 & 2.792 & 1.435 \\
\hline York River (YR) & 0.639 & 4.678 & 3.731 & & 54.986 & 7.734 & 3.764 & 4.641 & 1.994 \\
\hline South Bay (SB) & 0.682 & 6.234 & 5.663 & 4.945 & & 10.448 & 5.402 & 5.243 & 2.380 \\
\hline Hog Island Bay (HR6) & 1.362 & 8.608 & 6.058 & 8.245 & 9.235 & & 13.327 & 17.192 & 3.632 \\
\hline Hog Island Bay (HR7) & 1.307 & 4.366 & 2.194 & 2.603 & 4.974 & 10.833 & & 6.449 & 3.485 \\
\hline Spider Crab Bay (SC) & 1.280 & 7.123 & 4.049 & 4.089 & 6.800 & 13.257 & 6.953 & & 10.536 \\
\hline Chincoteague Bay $(\mathrm{CH})$ & 1.362 & 3.262 & 3.311 & 2.689 & 3.680 & 4.233 & 4.089 & 4.705 & \\
\hline
\end{tabular}

which reduces competition and thus seedling survival. Phillips et al. (1983) showed that Zostera marina flowering increased due to environmental stress and disturbance, which suggests an increase in the source of seeds in disturbed areas. Modeling of clonal terrestrial plants has shown that frequent disturbance and high seedling recruitment can increase overall genotypic diversity (Watkinson \& Powell 1993).

Seeds used in the coastal bay restoration sites were collected from as far as $80 \mathrm{~km}$ away, as no local source populations were available from the Virginia coastal bays. We detected no direct evidence of genetic erosion through outbreeding depression. Outbreeding depression occurs when locally adapted genotypes interbreed with non-adapted genotypes, resulting in reduced fitness of the progeny (Hufford \& Mazer 2003), and usually occurs when different populations mix. Another potential genetic impact of population mixing is heterosis, often referred to as hybrid vigor, that occurs when deleterious alleles are masked or when an increase in heterozygosity results in progeny which are fitter relative to their parents (Hufford \& Mazer 2003). Although heterosis is a positive effect of genetic mixing among the first-generation population hybrids, the next generation may experience reduced fitness as deleterious genetic traits are expressed in future generations. Since genetic structure was maintained by restoration with seeds, as long as donor sites are chosen carefully, these problems are more likely to be minimized.

The use of donor material for restoration from the closest populations, the coastal bay meadows in Chincoteague Bay $(\mathrm{CH})$ or the very small population at the mouth of Chesapeake Bay (FI), may result in problems not encountered when Chesapeake Bay populations were used as donors. These 2 natural meadows in the Virginia coastal bay region have little gene flow and relatively high $F_{\text {st }}$ values among them and with Chesapeake Bay to the west $\left(N_{\mathrm{m}}\right.$ ranges between 1.362 and $\left.1.588, F_{\text {st }}=0.136\right)$ (Tables $2 \& 5$ ). Because they are geographically separated and differ genetically, it is possible they may have acquired distinct adaptations through either genetic drift or due to selection for fitness to local conditions. Using seeds from these locations could result in outbreeding depression if environmental conditions differ from those in the restoration sites.

We observed the genetic signature of Chincoteague Bay in the restored Virginia coastal bays, principally Hog Island Bay (HB6). When all samples were analyzed using a Baysian cluster model, 4 distinct genetic clusters emerged, with Chincoteague Bay being relatively unique, except for a few samples in the more northern coastal bays (Fig. 4). This genetic signature could have been the result of 2 alternative mechanisms. First, small-scale $\left(4 \mathrm{~m}^{2}\right)$ test plots in South Bay seeded in 1999 used plants from Chincoteague Bay. These plots spread rapidly, and it is possible that flowering shoots with seeds could have drifted to Hog Island Bay and released seeds. Alternatively, flowering shoots with seeds could have drifted out of Chincoteague Bay south along the Atlantic coast and entered the coastal inlet near Hog Island Bay, releasing seeds as they floated over the bay. Flowering shoots with mature seeds can disperse long $(150 \mathrm{~km})$ distances (Harwell \& Orth 2002, Källström et al. 2008), and it was suggested that natural recruits observed in 1997 in South Bay may indeed have developed from Chincoteague populations (Harwell \& Orth 2002). Based on these previous studies, the Virginia coastal bays are within the colonization envelope of Chincoteague Bay Zostera marina populations. The detection of Virginia coastal bay $Z$. marina populations that share a specific genetic signal with Chincoteague Bay (Fig. 4) suggests recruitment via such long-distance dispersal events is likely occurring, although a more 
targeted analysis would be needed to confirm the most likely source. Natural recruitment into the area suggests that a slow recovery may have already begun before restoration intervention was initiated.

The present study demonstrates that large-scale Zostera marina restoration with seed as the source of propagules maintains comparable levels of genetic diversity in donor populations. The donor meadows used in our study had a high genetic diversity, and the subsequent high diversity in the restored areas likely contributed to the success of the restoration by increasing resistance to ecosystem disturbances (for discussion see Hughes \& Stachowicz 2004, 2011, Reusch et al. 2005). The positive effect of high genetic diversity is not limited to marine systems, and the use of seeds in the restoration of clonal terrestrial plants might also be advantageous. It should be noted that the Virginia coastal bays experience good water quality (www1.vcrlter.virginia.edu/home1/?q=data $\mathrm{wq})$, and this has undoubtedly been important to the restoration success in this area given that eutrophication is the most common cause of seagrass loss (Orth et al. 2006a). Where restoration attempts are made with marginal water quality, stresses and disturbances are likely to reduce plant growth and survival. Previous studies suggest that genetically diverse assemblages of seagrass will be better at surviving disturbances, such as intense grazing events, temperature stress, and algal blooms (Hughes \& Stachowicz 2004, 2011, Reusch et al. 2005). The present study also suggests that source material for $Z$. marina restoration can be collected from a relatively great distance away from the recipient site without a concern for genetic problems such as outbreeding depression.

The maintenance of genetic diversity can be used as one measure of restoration success, since high genetic diversity is associated with increased benefits for plant survival and ecosystem services (Booy et al. 2000). In our system, we demonstrate a method of restoration that maintains genetic diversity, and the results of that restoration are positive in terms of increased seagrass coverage and feedbacks on sediment and water-quality characteristics (Hanson \& Reidenbach 2012 this Theme Section, McGlathery et al. 2012 this Theme Section, Orth et al. 2012 this Theme Section).

Acknowledgements. Support of this study was provided by the Virginia Coast Reserve LTER project, which was supported by National Science Foundation grant DEB-0621014, and by the Jones Environmental Research Endowment to the Department of Environmental Sciences at the University of Virginia. This is contribution \#3202 from the Virginia Institute of Marine Science.

\section{LITERATURE CITED}

Booy G, Hendriks RJJ, Smulders MJM, Van Groenendael JM, Vosman B (2000) Genetic diversity and the survival of populations. Plant Biol 2:379-395

Campanella JJ, Bologna PAX, Smith SM, Rosenzweig EB, Smalley JV (2009) Zostera marina population genetics in Barnegat Bay, New Jersey, and implications for grass bed restoration. Popul Ecol 52:181-190

Cottam C (1934) Past periods of eelgrass scarcity. Rhodora 36:261-264

Cottam C (1935) Further notes on past periods of eelgrass scarcity. Rhodora 37:269-271

Cottam C, Munro DA (1954) Eelgrass status and environmental relations. J Wildl Manage 18:449-460

Coyer JA, Miller KA, Engle JM, Veldsink J, Cabello-Pasini A, Stam WT, Olsen JL (2007) Eelgrass meadows in the California Channel Islands and adjacent coast reveal a mosaic of two species, evidence for introgression and variable clonality. Ann Bot 101:73-87

Evanno G, Regnaut S, Goudet J (2005) Detecting the number of clusters of individuals using the software STRUCTURE: a simulation study. Mol Ecol 14:2611-2620

Goudet J (2001) FSTAT, a program to estimate and test gene diversities and fixation indices (Version 2.9.3). Available at: www.unil.ch/izea/softwares/fstat.html (accessed on 28 December 2011)

Green EP, Short FT (2003) World atlas of seagrass. University of California Press, Berkeley, CA

> Greening H, Janicki A (2006) Toward reversal of eutrophic conditions in a subtropical estuary: water quality and seagrass response to nitrogen loading reductions in Tampa Bay, Florida, USA. Environ Manage 38:163-178

Halpern BS, Walbridge S, Selkoe KA, Kappel CV and others (2008) A global map of human impact on marine ecosystems. Science 319:948-952

Hansen JCR, Reidenbach MA (2012) Wave and tidally driven flows in eelgrass beds and their effect on sediment suspension. Mar Ecol Prog Ser 448:271-287

Harwell MC, Orth RJ (2002) Long-distance dispersal potential in a marine macrophyte. Ecology 83:3319-3330

Hufford KM, Mazer SJ (2003) Plant ecotypes: genetic differentiation in the age of ecological restoration. Trends Ecol Evol 18:147-155

> Hughes AR, Stachowicz JJ (2004) Genetic diversity enhances the resistance of a seagrass ecosystem to disturbance. Proc Natl Acad Sci USA 101:8998-9002

Hughes AR, Stachowicz JJ (2011) Seagrass genotypic diversity increases disturbance response via complementarity and dominance. J Ecol 99:445-453

Jackson JBC, Kirby MX, Berger WH, Bjorndal KA and others (2001) Historical overfishing and the recent collapse of coastal ecosystems. Science 293:629-637

Johnson MTJ, Lajeunesse MJ, Agrawal AA (2006) Additive and interactive effects of plant genotypic diversity on arthropod communities and plant fitness. Ecol Lett 9: $24-34$

> Källström B, Nyqvist A, Åberg P, Bodin M, André C (2008) Seed rafting as a dispersal strategy for eelgrass (Zostera marina). Aquat Bot 88:148-153

Knapp EE, Dyer AR (1998) When do genetic considerations require special approaches to ecological restoration? In: Fiedler PL, Kareiva, P (eds) Conservation biology for the coming decade. Chapman \& Hall, New York, NY, p 345-363 
Kuehler C, Lieberman A, Oesterle P, Powers T and others (2000) Development of restoration techniques for Hawaiian thrushes: collection of wild eggs, artificial incubation, hand-rearing, captive-breeding, and re-introduction to the wild. Zoo Biol 19:263-277

Lotze HK, Lenihan HS, Bourque BJ, Bradbury RH and others (2006) Depletion, degradation, and recovery potential of estuaries and coastal seas. Science 312:1806-1809

Marion SR, Orth RJ (2010) Innovative techniques for largescale seagrass restoration using Zostera marina (eelgrass) seeds. Restor Ecol 18:514-526

McGlathery KJ, Reynolds LK, Cole LW, Orth RJ, Marion SR, Schwarzschild A (2012) Recovery trajectories during state change from bare sediment to eelgrass dominance. Mar Ecol Prog Ser 448:209-221

Moore KA, Jarvis JC (2008) Environmental factors affecting recent summertime eelgrass diebacks in the lower Chesapeake Bay: implications for long-term persistence. J Coast Res 55:135-147

Olsen JL, Stam WT, Coyer JA, Reusch TBH and others (2004) North Atlantic phylogeography and large-scale population differentiation of the seagrass Zostera marina L. Mol Ecol 13:1923-1941

Ort BS, Cohen SB, Boyer KE, Wyllie-Echeverria S (2010) Planning for eelgrass restoration in San Francisco Bay: genetic considerations. Report prepared for the California State Coastal Conservancy and Ocean Protection Council, Interagency Agreement No. 05-103. ,

Orth RJ (1975) Destruction of eelgrass, Zostera marina, by the cownose ray, Rhinoptera bonasus, in the Chesapeake Bay, Virginia. Chesap Sci 16:205-208

Orth RJ (1976) The demise and recovery of eelgrass, Zostera marina, in the Chesapeake Bay, Virginia. Aquat Bot 2: 141-159

Orth RJ, Moore KA (1983) Chesapeake Bay: an unprecedented decline in submerged aquatic vegetation. Science 222:51-53

> Orth RJ, Moore KA (1984) Distribution and abundance of submerged aquatic vegetation in Chesapeake Bay-a historical perspective. Estuaries 7:531-540

> Orth RJ, Carruthers TJB, Dennison WC, Duarte CM and others (2006a) A global crisis for seagrass ecosystems. Bioscience 56:987-996

Orth RJ, Luckenbach ML, Marion SR, Moore KA, Wilcox DJ (2006b) Seagrass recovery in the Delmarva coastal bays, USA. Aquat Bot 84:26-36

Orth RJ, Marion SR, Moore KA, Wilcox DJ (2010) Eelgrass (Zostera marina L.) in the Chesapeake Bay region of mid-Atlantic coast of the USA: challenges in conservation and restoration. Estuar Coast 33:139-150

> Orth RJ, Moore KA, Marion SR, Wilcox DJ, Parrish DB (2012) Seed addition facilitates eelgrass recovery in a coastal bay system. Mar Ecol Prog Ser 448:177-195

Ostermann SD, Deforge JR, Edge WD (2001) Captive breeding and reintroduction evaluation criteria: a case study of peninsular bighorn sheep. Conserv Biol 15:749-760

Paling EI, Fonseca M, van Katwijk MM, van Keulen M (2009) Seagrass restoration. In: Perillo GME, Wolanski E, Cahoon DR, Brinson M (eds) Coastal wetlands: an integrated ecosystems approach. Elsevier, Amsterdam, p 687-713

> Peakall R, Smouse PE (2006) Genalex 6: genetic analysis in Excel. Population genetic software for teaching and research. Mol Ecol Notes 6:288-295

Phillips RC, McMillan C, Bridges KW (1983) Phenology of eelgrass, Zostera marina L., along latitudinal gradients in
North America. Aquat Bot 15:145-156

Pritchard JK, Stephens M, Donnelly P (2000) Inference of population structure using multilocus genotype data. Genetics 155:945-959

Rasmussen E (1977) The wasting disease of eelgrass (Zostera marina) and its effects on environmental factors and fauna. In: McRoy CP, Helfferich C (eds) Seagrass ecosystems. Marcel Dekker, New York, NY, p 1-51

Reed DH, Frankham R (2003) Population fitness is correlated with genetic diversity. Conserv Biol 17:230-237

Reusch TBH, Stam WT, Olsen JL (1999) Microsatellite loci in eelgrass Zostera marina reveal marked polymorphism within and among populations. Mol Ecol 8:317-321

Reusch TBH, Stam WT, Olsen JL (2000) A microsatellitebased estimation of clonal diversity and population subdivision in Zostera marina, a marine flowering plant. Mol Ecol 9:127-140

> Reusch TBH, Ehlers A, Hammerli A, Worm B (2005) Ecosystem recovery after climatic extremes enhanced by genotypic diversity. Proc Natl Acad Sci USA 102:2826-2831

Short FT, Polidoro P, Livingstone SR, Carpenter KE and others (2011) Extinction risk assessment of the world's seagrass species. Biol Conserv 144:1961-1971

Talbot SL, Sage GK, Rearick JR, Muñiz-Salazar R (2004) Genetic structure of Zostera marina in San Francisco Bay. Report to the baywide eelgrass inventory and habitat management research program. NOAA Fisheries \& Caltrans, San Francisco, CA

van Katwijk MM, Bos AR, de Jonge VN, Hanssen LSAM, Hermus DCR, de Jong DJ (2009) Guidelines for seagrass restoration: importance of habitat selection and donor population, spreading of risks, and ecosystem engineering effects. Mar Pollut Bull 58:179-188

Waples R (1991) Pacific salmon, Oncorhynus spp., and the definition of 'species' under the Endangered Species Act. Mar Fish Rev 53:11-22

- Waples RS (1994) Genetic considerations in recovery efforts for Pacific salmon. Conserv Biol 8:884-886

Watkinson AR, Powell JC (1993) Seedling recruitment and the maintenance of clonal diversity in plant populations - a computer simulation of Ranunculus repens. J Ecol 81:707-717

- Waycott M, Duarte CM, Carruthers TJB, Orth RJ and others (2009) Accelerating loss of seagrasses across the globe threatens coastal ecosystems. Proc Natl Acad Sci USA 106:12377-12381

Williams S (2001) Reduced genetic diversity in eelgrass transplantations affects both individual and population fitness. Ecol Appl 11:1472-1488

> Williams SL, Davis CA (1996) Population genetic analyses of transplanted eelgrass (Zostera marina) beds reveal reduced genetic diversity in southern California. Restor Ecol 4:163-180

Wyllie-Echeverria S, Talbot SL, Rearick JR (2010) Genetic structure and diversity of Zostera marina (eelgrass) in the San Juan Archipelago, Washington, USA. Estuar Coast 33:811-827

> Yoshida T, Okamoto H, Tanaka Y, Hibino T, Suzuki T, Takabe $\mathrm{T}$ (2009) Reproduction dynamics of eelgrass (Zostera marina L.) populations in Ise-Mikawa Bay, central Honshu, Japan. Plant Species Biol 24:202-208

Zhu GY, Kinet JM, Bertin P, Bouharmont J, Lutts S (2000) Crosses between cultivars and tissue culture-selected plants for salt resistance improvement in rice, Oryzasativa. Plant Breed 119:497-504 